DOI.

https://doi.org/10.22219/fths.v2i2

Received: Mei 2019

Accepted: Juni 2019

Available online: Juli 2019

\title{
Karakteristik Sifat Fisiko-Kimia Mi Basah Subtitusi Tepung Sorgum (Sorghum bicolor L. Moench) Diperkaya Serat Rumput Laut (Gracilaria sp.)
}

\author{
Alifianti Nur Waqiah ${ }^{1}$, Damat ${ }^{2}$, Desiana ${ }^{*}$ \\ ${ }^{1}$ Program Studi Teknologi Pangan, Fakultas Pertanian Peternakan, Universitas Muhammadiyah \\ Malang, Malang, Indonesia \\ "Corresponding author email: desiana@umm.ac.id
}

\begin{abstract}
Noodles is consisting with main high protein flour. Data consumption of noodles on 2014 in Indonesia gain 2,2 million ton, this number were going high gradually in every next year. The subtitute material which is have similary with wheat have been used in last decade is sorghum starch. The aim of this study was to determine the effect of the composition of sorghum starch with seaweed pulp. The research method in is: factorial Randomized Block Design (RBD). The first factor used was the difference in the ratio of wheat flour with sorghum starch which was added at 80:20; 60:40; 50:50 Factor II is the addition of seaweed which is $10 \%, 20 \%$, and $30 \%$. Quality starch noodles with in analysis: water content, ash content, protein content, fat content, crude fiber content, and organoleptic (texture, taste, color and aroma (smell)). The best results were obtained in the T1R1 treatment which got rank 1 with water content $33.38 \%$, ash content $2.05 \%$, protein content $8.31 \%$, fiber content $12.92 \%$, fat content $1.22 \%$, organoleptic aroma 2.94 with aroma value "Quite tasty", organoleptic texture 3.76 with a value of "springy", color organoleptic 3.73 which is "attractive", organoleptic taste 3.76 that is "delicious".
\end{abstract}

Keywords: seaweed, sorghum Flour, wet noodles

\section{PENDAHULUAN}

Sorghum (Sorghum bicolor L. Moench) merupakan tanaman serealia selain padi, gandum, jagung, dan barley. Sorgum merupakan sumber pangan yang sangat potensial bagi masyarakat Indonesia karena dapat dibudidayakan pada lahan kering dan mudah beradaptasi di lahan marginal. Biji sorghum bisa dimanfaatkan anatara lain sebagai pangan, pakan, maupun bahan baku industri, dan daunnya dapat digunakan untuk pakan ternak. Sorgum memiliki nilai nutrisi 3,1\% lemak, lebih tinggi dibandingkan dengan gandum $2 \%$ per $100 \mathrm{~g}$, serta kadar serat 2,74\% (Suarni, 2001).

Mi merupakan produk makanan dengan bahan baku tepung terigu yang sangat populer di Indonesia. Produk mi biasanya digunakan sebagai sumber energi karena mi memiliki karbohidrat cukup tinggi (Rustandi, 2011). Rumput laut sebagai bahan pangan sudah dimanfaatkan tetapi pemanfaatannya masih sangat terbatas sebagai sayur atau lauk. Kandungan gizi rumput laut antara 
lain protein, karbohidrat, sedikit lemak dan abu (yang merupakan senyawa garam natrium dan kalium). Dengan adanya rumput laut pada campuran adonan mi basah diharapkan dapat menambah kadar serat pada mi basah. Serat kasar yang ada pada rumput laut dalam pencampuran mi sangat berpengaruh pada tekstur mi (Murniyati, dkk., 2010).

Sifat keunggulan produk mi ini merupakan kaya akan serat yang memiliki sifat resistan terhadap proses pencernaan, sehingga penyerapan di usus halus manusia sulit terjadi. Hal ini disebabkan serat pangan merupakan bagian dari bahan pangan yang tidak dapat dihidrolisis oleh enzim-ennzim pencernaan, sehingga dapat menahan rasa lapar lebih lama (Muhandri, 2013).

Proses pembuatan mi basah dengan penambahan subtitusi tepung sorgum dan penambahan rumput laut diharapkan dapat meningkatkan gizi terutama serat. Oleh sebab itu, peneliti tertarik untuk mengangkat tema skripsi yang berjudul "Karakteristik Sifat Fisiko-Kimia Mi Basah Subtitusi Tepung Sorgum (Sorghum bicolor L. Moench) Diperkaya Serat Rumput Laut (Gracilaria sp.)”

\section{METODE PENELITIAN}

\section{Bahan}

Bahan yang digunakan dalam penelitian ini adalah tepung terigu berprotein tinggi $12-13 \%$ tepung sorgum, rumput laut Gracilia sp., STPP (Sodium tripolyphosphate).

Alat

Alat yang digunakan dalam penelitian ini adalah desikator, tanur, timbangan analitik merk Ohaus tipe PA413, hot plate merk Maspion S-30.

\section{Preparasi bubur rumput laut}

Rumput laut (Gracilaria sp) dicuci, kemudian direndam di dalam air tawar sebanyak 10 kali dari berat rumput laut (hingga rumput laut terendam) selama 12 jam. Setelah direndam rumput laut dibilas dengan air bersih dan ditiriskan, kemudian rumput laut dipotong kecil-kecil. Rumput laut kemudian dijadikan bubur dengan penambahan air 1:1 menjadi bubur rumput laut dengan menggunakan blender. Bubur rumput laut dicampur dengan tepung sesuai formulasi sebanyak masing-masing 10\%, 20\%, 30\% (Meldasari, 2013).

\section{Pembuatan Mie Basah}

Formulasi tepung terigu dengan tepung sorgum masing-masing diberi bubur rumput laut dengan konsentrasi 30\%, 20\%, 10\%. Kemudian ke dalam campuran bahan ditambahkan garam, putih telur, dan STPP. Campuran formulasi diaduk dengan mixer dan ditambahkan air hingga didapatkan adonan yang homogen dan tidak lengket. Selanjutnya adonan dimasukkan ke dalam alat ampia (pengepres mi) sedikit demi sedikit. Lembaran dimasukkan ke dalam cetakan mi (pembentuk benang mi) sehingga didapat untaian mi dan mi ditaburi sedikit terigu agar tidak lengket, setelah itu dianalisis (Amelia, 2018). 


\section{Parameter Penelitian}

Analisis yang dilakukan dalam penelitian ini meliputi analisis kadar air metode thermogravimetri (AOAC, 2005), kadar abu metode pengabuan (AOAC, 2005), protein metode mikro-Kjeldahl (AOAC, 2005), lemak metode Soxhlet (AOAC, 2005), kadar serat kasar (AOAC, 2005), uji organoleptik rasa, aroma, tekstur, dan kenampakan. Analisa perlakuan terbaik metode modus.

\section{Rancangan Percobaan dan Analisa Data}

Penelitian ini dilakukan dengan menggunakan Rancangan Acak Kelompok (RAK) Faktorial, dengan dua faktor. Faktor I adalah formulasi tepung terigu dengan tepung sorgum (tepung terigu : tepung sorgum) yakni 80\%:20\% ; 60\%:40\%; 50\%:50\%. Faktor II yaitu konsentrasi rumput laut 30\%, 20\%, 10\%. Perlakuan yang dilakukan adalah: T1R1, T1R2, T1R3, T2R1, T2R2, T2R3, T3R1, T3R2, T3R3, kontrol, yang dilakukan pengulangan 3 kali.

Pengolahan data yang dilakukan pada penelitian ini adalah menggunakan analisis ragam (ANOVA) dengan uji $\mathrm{F}$ pada taraf $5 \%$. Apabila terjadi pengaruh nyata pada masing-masing perlakuan, maka yang dilakukan adalah data yang diperoleh dilanjutkan dengan uji pembeda menggunakan uji DMRT (Duncan's Multiplerange Test) (De garmo et al, 1984).

\section{HASIL DAN PEMBAHASAN}

Kadar Air

Berdasarkan hasil uji ragam diketahui bahwa terdapat tidak ada interaksi antara perbedaan konsentrasi tepung terigu dan sorgum dengan rumput laut terhadap kadar air pada mi basah. perlakuan perbedaan konsentrasi tepung terigu dengan sorgum tidak berpengaruh nyata terhadap kadar air mi basah. Hal ini karena bahan baku utama pembuatan mie basah yaitu tepung terigu yang memiliki kadar air rendah.

Prinsip penentuan kadar air dengan pengeringan adalah penguapan air yang ada dalam sampel dengan jalan pemanasan. Setelah itu dilakukan penimbangan pada bahan hingga berat konstan yang mengindikasikan bahwa semua air yang terkandung didalam sampel telah teruapkan semua.

Hasil analisa kadar air pada mie basah dengan proporsi tepung terugu dan tepung sorgum menunjukkan bahwa kadar air tidak memiliki perbedaan yang signifikan. Penambahan tepung sorgum menghasilkan kadar air yang lebih tinggi darii kadar air perlakuan kontrol (100\% tepung terigu), hal tersebut dapat disebabkan oleh kandungan kadar air pada tepung sorgum 13$13,5 \%$, sedangkan tepung terigyu memiliki kadar air 12\% (Kent, 2003). 
Tabel 1. Hasil Analisis Kadar Proksimat Mi Basah

\begin{tabular}{llllll}
\hline Proporsi TT:TS, RL & $\begin{array}{l}\text { Kadar } \\
\text { Air (\%) }\end{array}$ & $\begin{array}{l}\text { Kadar } \\
\text { Abu (\%) }\end{array}$ & $\begin{array}{l}\text { Kadar } \\
\text { Lemak } \\
(\%)\end{array}$ & $\begin{array}{l}\text { Kadar } \\
\text { Protein } \\
(\%)\end{array}$ & $\begin{array}{l}\text { Kadar } \\
\text { Serat(\%) }\end{array}$ \\
\hline T1R1 (80\%:20\%, 10\%) & $33,38^{\mathrm{a}}$ & $2,05^{\mathrm{a}}$ & $1,22^{\mathrm{a}}$ & $8,31^{\mathrm{c}}$ & $12.92^{\mathrm{b}}$ \\
T1R2 $(80 \%: 20 \%, 20 \%)$ & $34,66^{\mathrm{a}}$ & $2,22^{\mathrm{a}}$ & $1,13^{\mathrm{a}}$ & $8,12^{\mathrm{c}}$ & $14,75^{\mathrm{c}}$ \\
T1R3 $(80 \%: 20 \%, 30 \%)$ & $40,36^{\mathrm{d}}$ & $2,03^{\mathrm{a}}$ & $1,23^{\mathrm{a}}$ & $8,32^{\mathrm{c}}$ & $18,20^{\mathrm{f}}$ \\
T2R1 (60\%:40\%,10\%) & $34,73^{\mathrm{a}}$ & $2,29^{\mathrm{a}}$ & $1,44^{\mathrm{b}}$ & $7,55^{\mathrm{b}}$ & $15,04^{\mathrm{c}}$ \\
T2R2 (60\%:40\%, 20\%) & $36,29^{\mathrm{c}}$ & $1,73^{\mathrm{a}}$ & $1,57^{\mathrm{b}}$ & $7,51^{\mathrm{b}}$ & $16,55^{\mathrm{d}}$ \\
T2R3 (60\%:40\%, 30\%) & $37,81^{\mathrm{c}}$ & $1,56^{\mathrm{a}}$ & $1,61^{\mathrm{b}}$ & $7,62^{\mathrm{b}}$ & $17,65^{\mathrm{e}}$ \\
T3R1 (50\%:50\%, 10\%) & $35,04^{\mathrm{b}}$ & $2,06^{\mathrm{a}}$ & $1,78^{\mathrm{c}}$ & $6,45^{\mathrm{a}}$ & $16,68^{\mathrm{d}}$ \\
T3R2 (50\%:50\%, 20\%) & $35,24^{\mathrm{b}}$ & $2,05^{\mathrm{a}}$ & $1,81^{\mathrm{d}}$ & $6,32^{\mathrm{a}}$ & $19,03^{\mathrm{g}}$ \\
T3R3 (50\%:50\%,30\%) & $38,51^{\mathrm{d}}$ & $2,23^{\mathrm{a}}$ & $1,88^{\mathrm{d}}$ & $6,59^{\mathrm{a}}$ & $19,21^{\mathrm{g}}$ \\
kontrol (100\%) & $31,46^{\mathrm{a}}$ & $1,65^{\mathrm{a}}$ & $1,09^{\mathrm{a}}$ & $8,91^{\mathrm{d}}$ & $10,21^{\mathrm{a}}$ \\
\hline Ron
\end{tabular}

Nilai rata-rata yang diikuti oleh huruf yang sama menunjukkan tidak berbeda nyata dengan uji DMRT $5 \%$.

Keterangan :

TT : Tepung terigu

TS : Tepung Sorgum

RL : Rumput Laut

Perlakuan penambahan rumput laut berpengaruh sangat nyata terhadap kadar air pada mi basah yang dihasilkan. Hasil kadar air dari kontrol 31,64\%, rumput laut $10 \% 34,38 \%$, rumput laut $20 \% 35,4 \%$, rumput laut $30 \%$ menghasilkan $38,89 \%$ hal ini menunjukkan penambahan konsentrasi rumput laut mempengaruhi kadar air pada mi basah. Semakin tinggi konsentrasi rumput laut yang ditambahkan, kadar air juga meningkat, hal itu dikarenakan rumput laut memiliki sifat yang dapat memerangkap (adsorbtion) sejumlah air dalam adonan mi basah. Karagenan merupakan senyawa hidrokoloid yang memiliki kemampuan mengikat air. Menurut Gomez-Guillen dkk., (2006) nilai daya ikat air tinggi itu karena karagenan membengkak sehingga menambah elastisitas dengan mereduksi kandungan air serta meningkatkan kepadatan di sekitar matrik protein. Peningkatan daya ikat air oleh karagenan, menjaga atau menahan air dalam ruang matrix yang terbentuk.

\section{Kadar Abu}

Kadar abu pada perlakuan penambahan sorgum memiliki kadar abu yang lebih tinggi dibandingkan dengan perlakuan kontrol, hal tersebut dikarnakan tepung sorgum memiliki kandungan kadar abu yang lebih tinggi dibandingkan dengan tepung terigu (Suarni, 2001). Menurut Suarni (2001), tepung sorgum memiliki kandungan kadar abu sebesar 2,24\%, sedangkan tepung terigu memiliki kadar abu 1,83\%. Menurut Gartika (2007) menyatakan bahwa kandungan mineral dalam bahan pangan dapat diperkirakan sebagai 
kandungan kadar abu yang merupakan residu anorganik yang tersisa setelah bahan organik terbakar habis.

Rumput laut mengandung mineral yang tinggi, sehingga kadar abu yang dihasilkan lebih tinggi dari perlakuan kontrol. Manurut Farid (2013) kandungan kadar abu rumput laut Gracillaria sp. mengandung 19-21\% kadar abu berdasarkan berat kering.

\section{Kadar Lemak}

Berdasarkan uji DMRT taraf 5\% dapat diketahui bahwa perlakuan konsentrasi tepung sorgum yang ditambahkan memiliki perbedaan yang nyata terhadap kadar lemak mi basah. Penambahan tepung sorgum menghasilkan kadar kemak yang meningkat, hal itu terjadi karena tepung sorgum memiliki kandungan lemak lebih tinggi dari tepung terigu. Menurut Suarni (2001) sorgum memiliki kandungan lemak sebesar $3,65 \%$ sementara terigu memiliki kandungan lemak sebesar 2,09\%. Rumput laut berpengaruh terhadap kadar lemak yang dihasilkan. Menurut Ito (2009), kadar lemak rumput laut berkisar antara $0,2-3,8 \%$.

\section{Kadar Protein}

Rata-rata kadar protein mi basah dengan perbandingan konsentrasi tepung terigu dengan sorgum memberikan pengaruh sangat nyata. Menurut Suarni (2001) kadar protein tepung terigu sebesar 14,45\%, sedangkan kadar protein sorgum sebesar $10,11 \%$. Hal ini menyebabkan penambahan tepung sorgum yang diiringi dengan berkurangnya terigu yang digunakan pada pembuatan mi basah akan menurunkan kadar protein mi basah tersebut.

Rata-rata pada perlakuan penambahan rumput laut menghasilkan kadar protein sebesar 7,44\%-7,51\%, hal ini menunjukkan tidak adanya perbedaan nyata terhadap kadar protein yang dihasilkan.

\section{Kadar Serat}

Berdasarkan uji Duncan 5\% diketahui bahwa terdapat perbedaan analisa kadar serat menunjukkan jumlah nilai rerata tertinggi sebesar 19,21\% pada perlakuan T3R3 yaitu perbedaan perbandingan tepung terigu dengan sorgum 50:50 dan penambahan rumput laut 30\%.

Semakin tinggi penambahan konsentrasi tepung sorgum dan rumput laut mempengaruhi tingginya kadar serat pada mi basah yang dihasilkan. Hal ini dikarenakan kadar serat pada tepung sorgum lebih tinggi dari kadar serat tepung terigu. Kadar serat tepung sorgum sebesar 2,74\% sedangkan kadar serat pada tepung terigu sebesar 1,92\% (Suarni, 2001). 
Tabel 2. Hasil Analisis Organoleptik Mi Basah

\begin{tabular}{lllll}
\hline Proporsi TT:TS, RL & Rasa & Aroma & Tekstur & warna \\
\hline T1R1 $(80 \%: 20 \%, 10 \%)$ & $3,76^{\mathrm{d}}$ & $2,94^{\mathrm{c}}$ & $3,42^{\mathrm{e}}$ & $3,73^{\mathrm{d}}$ \\
T1R2 $(80 \%: 20 \%, 20 \%)$ & $3,28^{\mathrm{c}}$ & $3,00^{\mathrm{c}}$ & $2,69^{\mathrm{c}}$ & $3,21^{\mathrm{c}}$ \\
T1R3 $(80 \%: 20 \%, 30 \%)$ & $2,79^{\mathrm{b}}$ & $2,54^{\mathrm{b}}$ & $2,00^{\mathrm{b}}$ & $2,50^{\mathrm{b}}$ \\
T2R1 $(60 \%: 40 \%, 10 \%)$ & $3,42^{\mathrm{c}}$ & $3,66^{\mathrm{d}}$ & $2,88^{\mathrm{c}}$ & $2,21^{\mathrm{a}}$ \\
T2R2 (60\%:40\%, 20\%) & $3,46^{\mathrm{c}}$ & $3,64^{\mathrm{d}}$ & $3,28^{\mathrm{d}}$ & $2,09^{\mathrm{a}}$ \\
T2R3 (60\%:40\%, 30\%) & $2,30^{\mathrm{a}}$ & $2,00^{\mathrm{a}}$ & $2,10^{\mathrm{b}}$ & $4,00^{\mathrm{d}}$ \\
T3R1 (50\%:50\%, 10\%) & $2,53^{\mathrm{a}}$ & $3,80^{\mathrm{d}}$ & $4,00^{\mathrm{f}}$ & $3,00^{\mathrm{c}}$ \\
T3R2 (50\%:50\%, 20\%) & $2,46^{\mathrm{a}}$ & $2,53^{\mathrm{b}}$ & $1,51^{\mathrm{a}}$ & $2,53^{\mathrm{b}}$ \\
T3R3 (50\%:50\%, 30\%) & $2,28^{\mathrm{a}}$ & $2,40^{\mathrm{a}}$ & $1,30^{\mathrm{a}}$ & $2,05^{\mathrm{a}}$ \\
kontrol $(100 \%)$ & $3,95^{\mathrm{d}}$ & $3,80^{\mathrm{d}}$ & $4,54^{\mathrm{g}}$ & $5,00 \mathrm{e}$ \\
\hline
\end{tabular}

Nilai rata-rata yang diikuti oleh huruf yang sama menunjukkan tidak berbeda nyata dengan uji DMRT $5 \%$.

Keterangan :

TT : Tepung terigu

TS : Tepung Sorgum

RL : Rumput Laut

Pada penelitian Rufaizah (2011) penambahan sorgum sebanyak 25\% hingga $75 \%$ dari berat $100 \mathrm{~g}$ formula hanya menghasilkan serat $8,12 \%$ sampai $11,54 \%$, hal itu menunjukkan penambahan rumput laut juga berpengaruh terhadap kadar serat yang dihasilkan. Penambahan kadar rumput laut juga berpengaruh terhadap kadar serat mie basah yang dihasilkan, hal ini dikarenakan rumput laut berjenis Gracillaria sp. memiliki kandungan serat yang cukup tinggi yaitu 8,79\% (Farid, 2013).

Rumput laut jenis Gracilaria sp. mempunyai kandungan serat yang tinggi. Tingginya serat tersebut dikarenakan tingginya polisakarida pada sel rumput laut. Jumlah serat kasar merupakan jumlah dietary fiber dan fungsional fiber. Kebiasaan mengkonsumsi serat sangat bermanfaat untuk manusia yang menderita obesitas dan diabetes mellitus. Sifat fisiko kimia dari serat alga merah sama dengan serat yang tersedia pada makanan komersial yang kaya akan serat (Venugophal, 2010).

\section{Organoleptik Rasa}

Terjadi interaksi antara perbedaan perbandingan tepung terigu dan sorgum dengan konsentrasi rumput laut terhadap nilai organoleptik rasa mi basah. Rerata nilai organoleptik akibat perbedaan perbandingan tepung terigu dengan sorgum dan konsentrasi rumput laut dapat dilihat pada tabel. Perlakuan penambahan tepung sorgum dan rumput laut yang menghasilkan nilai rasa tinggi yaitu perlakuan T1R1 yang menghasilkan nilai rasa 3,76 yang berarti "Enak". Selain perlakuan kontrol dan T1R1 rata-rata menghasilkan nilai rasa "tidak enak" dan "cukup enak". 
Menurut winarno (1997), rasa dari suatu bahan makanan juga dapat dipengaruhi oleh kandungan karbohidrat yang terdapat di dalam bahan makanan tersebut. Selain itu sorgum mengandung senyawa antinutrisi, terutama tannin yang menyebabkan rasa sepat sehingga tidak disukai konsumen (Septaviani, 2014). Rumput laut yang ditambahkan juga mempengaruhi rasa yang dihasilkan mi basah. Aroma amis yang dihasilkan, membuat rangsangan terhadap rasa yang tidak enak sehingga tingkat kesukaan panelis menurun.

\section{Organoleptik Aroma}

Aroma merupakan sensasi bau yang ditimbulkan oleh rangsangan kimia, senyawa volatil yang tercium oleh syaraf-syaraf ketika bahan pangan masuk ke mulut. Rangsangan tersebut akan berpengaruh terhadap daya terima paneldalam suatu produk pangan (Winarno, 1997). Aroma yang dihasilkan mi basah terus menurun seiring penambahan rumput laut. Mi basah yang diberi perlakuan penambahan rumput laut menimbulkan aroma baru selain aroma normal, yaitu adanya aroma amis (Handayani, 2011). Rumput laut yang digunakan masih beraroma amis, sehingga mempengaruhi kwalitas dari mi basah yang dihasilkan.

\section{Organoleptik Tekstur}

Jumlah tepung sorgum yang digunakan untuk substitusi terigu dalam pembuatan produk mi cukup berpengaruh terhadap penerimaan panelis terhadap atribut elastisitas yang dihasilkan. Konsistensi gel tepung terigu lebih tinggi dibanding tepung sorgum (Suarni 2000). Oleh karena itu, makin tinggi penambahan tepung sorgum, konsistensi gel semakin rendah atau adonan mengeras. Serat kasar yang ada pada rumput laut dalam pencampuran mie sangat berpengaruh pada tekstur mie (Murniyati, dkk., 2010). Dengan meningkatnya konsentrasi rumput laut yang ditambahkan akan mempengaruhi tekstur mi basah menjadi kasar, hal itu dikarnakan kadar serat yang terkandung dalam rumput laut. Formula dengan subtitusi tepung sorgum sebanyak $20 \%$ lebih disukai para panelis dari pada konsentrasi $40 \%$ dan $50 \%$. Hal ini dikarenakan penggunaan tepung terigu yang semakin banyak akan menghasilkan elastisitas mi basah subtitusi sorgum yang semakin menyerupai elastisitas mi basah pada umumnya.

\section{Organoleptik Warna}

Berdasarkan hasil uji organoleptik warna didapatkan interaksi antara perbandingan tepung terigu dengan sorgum dan penambahan perbedaan konsentrasi rumput laut. Penambahan tepung sorgum menghasilkan warna yang tidak segar seperti kusam. Penambahan konsentrasi rumput laut yang semakin tinggi menghasilkan warna semakin kuning kehijauan yang terlihat 
tidak menarik. Peran warna pada produk pangan antara lain dapat merinci tenda-tanda kerusakan pada produk (Soekarto, 2002).

\section{Perlakuan Terbaik}

Pemilihan perlakuan terbaik digunakan untuk menentukan perlakuan mana yang terbaik dari suatu proses. Penentuan perlakuan terbaik dilakukan dengan menggunakan uji pembobotan dengan metode Modus. Prinsip pengujian ini adalah nilai yang sering muncul dan sesuai atau mendekati perssyaratan SNI.

Tabel 3. Uji Perlakuan terbaik

\begin{tabular}{lcc}
\hline \multicolumn{1}{c}{ Perlakuan } & T1R 1 & SNI Mi Basah \\
\hline Bau & Normal & Normal \\
Rasa & Normal & Normal \\
Warna & Normal & Normal \\
Tektur & Normal & Normal \\
Kadar air & $36,13 \%$ & $<35 \%$ \\
Kadar pro & $8,25 \%$ & $>9,0 \%$ \\
Kadar abu & $2,10 \%$ & $<0,05 \%$ \\
Kadar lemak & $1,19 \%$ & - \\
Kadar serat & $12,92 \%$ & - \\
\hline
\end{tabular}

Berdasarkan sifat fisikokimia, dan organoleptik berdasarkan perbedaan perbandingan tepung sorgum dengan tepung terigu dan konsentrasi rumput laut yang ditambahkan. Perlakuan terbaik terdapat pada perlakuan T1R1 yang dengan kadar air 33,38\%, kadar abu 2,05\%, kadar protein 8,31\%, kadar serat $12,92 \%$, kadar lemak 1,22\%, organoleptik aroma 2,94 dengan nilai aroma "cukup sedap", organoleptik tekstur 3,76 dengan nilai "kenyal", organoleptik warna 3,73 yaitu "menarik", organoleptik rasa 3,76 yaitu "enak".

\section{KESIMPULAN}

Perbedaan konsentrasi subtitusi sorgum dan konsentrasi rumput laut berinteraksi terhadap kadar serat dan organoleptik. Penggunaan perbedaan konsentrasi subtitusi sorgum berpengaruh nyata terhadap kadar lemak, protein. Penambahan konsentrasi rumput laut berpengaruh nyata terhadap kadar air. Hasil dari uji modus diketahui panelis lebih menyukai formula T1R1 yaitu penambahan subtitusi sorgum 20\% dan penambahan konsentrasi rumput laut $10 \%$. 


\section{REFERENSI}

Angkasa W.I, Purwoto H, Anggadireja J.T. 2011. Teknik Budidaya Rumput Laut. http://kenshuseidesu.tripod.com/id49.html [22 Februari 2019]

A.O.A.C. 2005. Official Methods of Analysis 18Th Edition. Association of Official Analytical Chemist. Washington DC. United State of America.

Astawan, M. 2006. Membuat Mie dan Bihun. Jakarta: Penebar Swadaya.

Badan Standarisasi Nasional. 2015. Standar Nasional Indonesia (SNI) 2987:2015: Syarat Mutu Mie Basah. Jakarta

Budijanto, S. dan Yulianti. .2012. Studi Persiapan Tepung Sorgum. Jurnal Teknologi Pertanian Vol. 13 No. 3 177-186. IPB. Bogor.

Ito, K. dan K. Hori. 2009. Seaweed: Chemical Composition and Potential Uses. Food Rev. Int. 5 (10): 101.

Kent, N.L. 2003. Technology of Cereal(3rd ed). Sydney: Pergamon Press.

Mardhatillah, H. 2018. Karakteristik Fisiko-Kimia Mie Basah Tinggi Protein Dengan Penambahan Serbuk Daun Kelor (Moringa Oleifera) Dan Karagenan (Euchema Cottonii) Sebagai Pengenyal. Skripsi UMM. Malang.

Meldasari, Y. 2013. Pengaruh Konsentrasi Rumput Laut (Eucheuma Cottonii) dan Jenis Tepung pada Pembuatan Mie Basah. Jurnal Penelitian Universitas Syiah Kuala. Aceh.

Muchtadi, T. R dan Sugiyono. 1992. Ilmu Pengetahuan Bahan Pangan. IPB, Bogor.

Muhandri, T., Subarna, I. Mustakim. 2013. Optimasi Proses Pembuatan Mi Sorgum dengan Menggunakan Ekstruder Ulir Ganda. JUrnal Sains Terapan 3(1): 1-8. Departemen Ilmu dan Teknologi Pangan IPB. Bogor.

Murniyati. Subaryono. dan Ika, Hermana. 2010. Pengolahan mie yang difortifikasi dengan ikan dan rumput laut sebagai sumber protein, serat kasar, dan iodium. Jurnal Pascapanen dan Bioteknologi Kelautan dan Perikanan. Vol. 5(1): 65-75

Rufaizah, U. 2011. Pemanfaatan Tepung Sorghum (Sorghum bicolor L. Moench) pada Pembuatan Snack Bar Tinggi Serat Pangan dan Sumber Zat Besi Untuk Remaja Puteri. Departemen Gizi Masyarakat. IPB. Bogor.

Rustandi, D. 2011. Produksi Mie. Tiga Serangkai Pustaka Mandiri, Solo.124 hlm. Suarni dan M. Hamdani. 2001. Potensi dan Penurunan Kuantitas Kandungan Gula Nira Beberapa Varietas Sorgum Manis Setelah Panen. Prosiding Seminar Nasional Pengelolaan Sumberdaya Alam untuk Mencapai Produktivitas Optimum. UNILA Lampung.

Sudarmadji, S., B. Haryono dan Suhardi. 1996. Analisa Bahan Makanan dan Pertanian. Liberty, Yogyakarta.

Tarwotjo, C.S. 2007. Dasar-Dasar Gizi Kuliner. Jakarta: Grasindo.

Venugopal V. 2010. Seafood Processing. New York: CRC Press.

Wibowo .S. 2015. Teknik Pengolahan Atc Dari Rumput Laut Eucheuma cottonii. Penebar Swadaya. Jakarta.

Widyaningsih, T.W, dan E.S. Murtini, 2006. Alternatif Pengganti Formalin Pada Produk Pangan. Surabaya: Trubus Agirasana.

Winarno, F.G. 1997. Kimia Pangan dan Gizi. PT. Gramedia Pustaka Utama, Jakarta. 